\title{
Adrenal interference of insulin secretion after 14-days oestradiol treatment in female rats
}

\author{
A. Faure, B. Billaudel and B.Ch.J.Sutter \\ Laboratoire de Physiologie Animale: Endocrinologie, UER de Biologie, Université de Bordeaux I, Talence, France
}

\begin{abstract}
Summary. Ovarian-adrenal interactions on insulin secretion during oestradiol treatment were studied in sham-operated, ovariectomized and adrenalectomized-ovariectomized female rats, the latter thus treated to suppress interference from endogenous hormones. Islets of Langerhans isolated from oestradiol or oestradiol + corticosterone treated and control rats were incubated with various glucose concentrations. Oestradiol treatment enhanced basal and glucose stimulated insulin secretion from sham-operated $(+12 \%)$ or ovariectomized rats $(+24 \%)$. This effect disappeared in adrenalectomized-ovariectomized rats but reappeared when adrenalectomized-ovari-
\end{abstract}

ectomized rats were treated with oestradiol + corticosterone $(+37 \%)$. A 14-day oestradiol treatment had a trophic effect on total protein content independent of adrenal presence $(+14 \% ;+15 \% ;+31 \% ;+23 \%$ versus respective control groups). Our data demonstrate that corticosterone is necessary for the stimulating effect of oestradiol on insulin secretion.

Key words: Rat, islets of Langerhans, oestradiol treatment, adrenal glands, corticosterone treatment, insulin.
The stimulatory effect of oestrogen treatment of glucose-induced insulin secretion is well established [1-5]. Because of the effect of oestradiol on the concentrations of other plasma steroids, the possibility of an indirect effect has been postulated [6-11]. Indeed, progesterone and corticosterone are enhanced particularly during oestradiol treatment [11] and these hormones are well known to interfere with insulin secretion $[2,10,12-16]$. Previous experiments in vivo have shown that hyperinsulinism induced by oestradiol treatment is more pronounced in ovariectomized rats and disappears in adrenalectomized-ovariectomized animals [11]. Thus the hypothesis arose that oestradiol acts on the $\beta$ cell via the glucocorticoids. In order to test this hypothesis, the effect of oestradiol on insulin secretion was studied in vitro, using islets of Langerhans isolated from 14-day oestradiol-treated or control rats in the following animal groups: sham-operated, ovariectomized or adrenalectomized-ovariectomized with or without corticosterone.

\section{Methods \\ Animals}

Female Wistar rats weighing $200-210 \mathrm{~g}$, aged 9 weeks, were kept in a temperature-controlled room at $22{ }^{\circ} \mathrm{C}$ with a $12 \mathrm{~h}$ lighting schedule $(07.00-19.00 \mathrm{~h})$; they had free access to standard laboratory chow and water. $\mathrm{NaCl}$ solution $(0.9 \%)$ substituted water after adrenalectomy. The animals were divided into four groups: (1) sham-operated, $n=10$; (2) ovariectomized, $n=12$; (3) adrenalectomized-ovariectomized, $n=17 ;$ (4) adrenalectomized-ovariectomized supplemented with corticosterone, $n=10$. After an 8-day post-operative recovery period, the rats received $\mathrm{SC}$ injections of $0.05 \mathrm{mg} / 0.1 \mathrm{ml} 17 \beta$-oestradiol twice daily for 14 days (Sigma Chemicals, St Louis, USA). Control animals received only the vehicle (ethanol and olive oil: $2.5 / 97.5, \mathrm{v} / \mathrm{v}$ ). Corticosterone supplementation was $0.2 \mathrm{mg}$ twice daily (Fluka, Buchs, Switzerland).

\section{Experimental procedures}

Islets of Langerhans were isolated by the method of Lacy and Kostianovsky [17]. Groups of five islets were assessed in plastic microtubes containing $1 \mathrm{ml}$ albumin Krebs-Ringer bicarbonate buffer with a nonstimulatory glucose concentration $(4.2 \mathrm{mmol} / \mathrm{l})$ and gassed for $1 \mathrm{~min}$ $\left(95 \% \mathrm{O}_{2}: 5 \% \mathrm{CO}_{2}\right)$. After a 30 -min pre-incubation period at $37^{\circ} \mathrm{C}$ in a shaking bath ( $60 \mathrm{rev} / \mathrm{min})$, the supernatant was discarded and the islets were washed with $0.1 \mathrm{ml}$ of the stimulating medium. Incubations were performed in $0.1 \mathrm{ml}$ of gassed Krebs Ringer bicarbonate buffer at various glucose concentrations: 4.2, 8.3, 11.1, 13.9, 16.7 and $33.3 \mathrm{mmol} / 1$. After $2 \mathrm{~h}$, insulin secretion was stopped by the addition of $0.9 \mathrm{ml}$ of Krebs Ringer buffer at $4^{\circ} \mathrm{C}$. The medium was then removed and kept at $-20^{\circ} \mathrm{C}$ until insulin determination. Islets were washed twice with $1 \mathrm{ml}$ Krebs Ringer buffer without albumin before lyophilization and sonification for protein determination.

\section{Analytical methods}

Insulin was assayed by a single antibody method [18] using rat insulin as a standard (Novo, Copenhagen, Denmark). Islet protein content 
Table 1. Protein content and insulin secretion in islets from control (oil-treated) or oestradiol-treated (14 days) rats

\begin{tabular}{|c|c|c|c|c|c|c|c|}
\hline \multirow{2}{*}{$\begin{array}{l}\text { Groups of animals } \\
\text { Sham-operated }\end{array}$} & \multirow{2}{*}{$\begin{array}{l}\text { Treatment } \\
\begin{array}{l}\text { Control } \\
\text { Oestradiol }\end{array}\end{array}$} & \multicolumn{2}{|c|}{ Protein content $(\mu \mathrm{g} /$ islet $)$} & \multicolumn{4}{|c|}{ Insulin secretion } \\
\hline & & $\begin{array}{l}0.96 \pm 0.03 \\
1.1 \pm 0.05^{\mathrm{b}}\end{array}$ & $\begin{array}{l}(30) \\
(30)\end{array}$ & $\begin{array}{l}124 \pm 5 \\
151 \pm 9^{c}\end{array}$ & $\begin{array}{l}(5) \\
(5)\end{array}$ & $\begin{array}{l}25.5 \pm 1 \\
28.6 \pm 1^{c}\end{array}$ & $\begin{array}{l}(5) \\
(5)\end{array}$ \\
\hline Ovariectomized & $\begin{array}{l}\text { Control } \\
\text { Oestradiol }\end{array}$ & $\begin{array}{l}1.03 \pm 0.03 \\
1.18 \pm 0.05^{\text {bd }}\end{array}$ & $\begin{array}{l}(36) \\
(36)\end{array}$ & $\begin{array}{l}121 \pm 11 \\
171 \pm 4^{\text {ad }}\end{array}$ & $\begin{array}{l}\text { (6) } \\
\text { (6) }\end{array}$ & $\begin{array}{l}23.9 \pm 1.4 \\
29.7 \pm 1.0^{\text {bf }}\end{array}$ & $\begin{array}{l}(6) \\
(6)\end{array}$ \\
\hline Adrenalectomized-ovariectomized & $\begin{array}{l}\text { Corticosterone } \\
\text { Corticosterone } \\
\text { + Oestradiol }\end{array}$ & $\begin{array}{l}0.88 \pm 0.06 \\
1.08 \pm 0.04^{\text {be }}\end{array}$ & $\begin{array}{l}(30) \\
(30)\end{array}$ & $\begin{array}{l}126 \pm 6 \\
191 \pm 11^{\mathrm{ad}}\end{array}$ & $\begin{array}{l}(5) \\
(5)\end{array}$ & $\begin{array}{l}26.7 \pm 1.4 \\
36.5 \pm 2^{\text {bd }}\end{array}$ & $\begin{array}{l}(5) \\
(5)\end{array}$ \\
\hline
\end{tabular}

Results are expressed as mean \pm SEM with number of assays in parentheses. Protein content per islet based on groups of five islets after the incubation assays. Insulin values are derived from the curve areas (see Figs. 1-4). Statistical analysis: ${ }^{\mathrm{a}} p<0.001,{ }^{b} p<0.01,{ }^{c} p<0.05$ versus their respective controls; ${ }^{\mathrm{d}} p<0.001,{ }^{\mathrm{e}} p<0.01,{ }^{\mathrm{f}} p<0.05$ versus sham controls

was measured by a colorimetric microdosage technique (Bio-Rad protein microassay: $1-20 \mu \mathrm{g}$ protein) [19].

\section{Calculations}

Results are expressed as mean \pm SEM. Statistical significance was established using the Student's t-test for unpaired samples. $\mathrm{n}$ is the number of assays from two or three consecutive experiments run in parallel and performed with islets from several rats. The curve areas of glucose dose-dependent insulin responses were calculated by trapezoïdal integration.

\section{Results}

\section{Total protein content of islets of Langerhans (Table 1)}

Islets protein content was determined on the groups of five islets used for incubation assays and after washing. This parameter was not affected by ovariectomy but was decreased after adrenalectomy and reversed in islets from adrenalectomized-ovariectomized rats receiving corticosterone. Oestradiol treatment increased the total protein content of islets in all the groups considered.

\section{Insulin secretion by isolated islets of Langerhans}

All the groups studied exhibited a dose-dependent insulin response to increasing glucose concentrations. The insulin response of islets from sham-operated or ovariectomized rats was not significantly different (Table 1 ) whereas it was reduced in the adrenalectomized-ovariectomized group and restored with corticosterone supplementation (Table 1). The same variations could be observed whether the results were expressed as ng of insulin or as ng insulin/ $\mu \mathrm{g}$ protein.

After oestradiol treatment, basal and glucose-induced insulin responses were increased in the sham-operated group (Table 1, Fig. 1) except at the highest glucose concentration $(33.3 \mathrm{mmol} / \mathrm{l})$. The same results were observed whether insulin values were expressed as $\mathrm{ng}$ or $\mathrm{ng} / \mu \mathrm{g}$ protein, though basal insulin values were not significantly different in the second form.

Islets from the ovariectomized oestradiol-treated group showed enhanced insulin secretion for basal and stimulatory glucose concentrations (Table 1, Fig.2) in whichever form the results were expressed except at the highest glucose concentration $(33.3 \mathrm{mmol} / \mathrm{l})$.

Insulin secretion of islets from oestradiol-treated adrenalectomized-ovariectomized rats was not significantly different from that of their own control adrenalectomized-ovariectomized group (Table 1, Fig. 3) and was also lower than in all other groups.

In the last group of animals without ovaries and adrenal glands but with corticosterone, basal and glucose-induced insulin responses were increased by oestradiol treatment (Table 1, Fig. 4) whichever expression mode was used. One must note that for the highest glucose concentration $(33.3 \mathrm{mmol} / \mathrm{l})$, insulin secretion which was already enhanced by corticosterone, was greater with corticosterone and oestradiol though this rise was not significant (Fig. 4). In addition, the insulin release curve tended to reach a maximum after $16.7 \mathrm{mmol} / 1$ glucose stimulation. This rise was not so clear cut in the other oestradiol-treated groups, but they all presented a non-significant rise of insulin release from $16.7 \mathrm{mmol} / 1$ to $33.3 \mathrm{mmol} / 1 \mathrm{glucose}$, whereas for the control group this rise was significant.

\section{Discussion}

Experiments in vivo have shown that $17-\beta$-oestradiol treatment of normal or ovariectomized rats induces a high plasma insulin concentration and an enhanced insulin response to intravenous glucose load [11]. This effect disappears when the adrenal glands are removed [11]; moreover oestradiol treatment has an inhibitory effect in adrenalectomized-ovariectomized rats which is only partially corrected by corticosterone supplementa- 

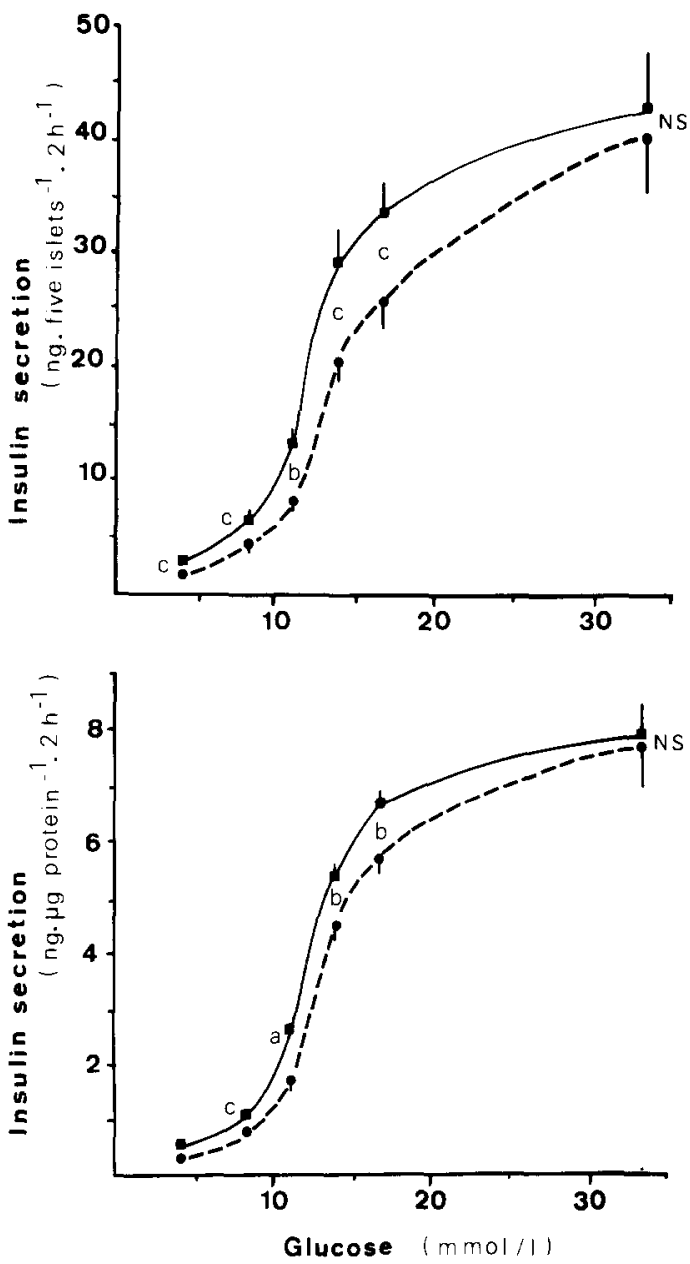

Fig. 1. Insulin secretion from islets of Langerhans isolated from shamoperated rats treated for 14 days with oestradiol $(\square \longrightarrow n=5)$ or with oil vehicle $(--0, n=5)$. Groups of five islets were incubated for $2 \mathrm{~h}$ in the presence of various glucose concentrations. Results are expressed as $\mathrm{ng}$ insulin or $\mathrm{ng} / \mu \mathrm{g}$ islet protein. Values are mean \pm SEM. Statistical analysis is applied for each glucose concentration between control and oestradiol groups: ${ }^{\mathrm{a}} p<0.001 ;{ }^{\mathrm{b}} p<0.01 ;{ }^{\mathrm{c}} p<0.05$

tion [11]. These in vivo observations suggest that the presence of the adrenal gland is necessary for oestradiol action on the $\beta$ cell; but they may also reflect the interaction between insulin secretion and insulin degradation. So, to determine the exact magnitude of the oestradiol effect on insulin secretion, studies were performed in vitro on isolated islets of Langerhans from 14-daytreated rats.

The present results of in vitro studies show that a 14-day oestradiol treatment increases insulin secretion in islets from ovariectomized rats in agreement with the cited in vivo experiments. They confirm earlier data obtained on the perfused pancreas [2,3] and in incubated $[1,4]$ or perifused [4] isolated islets. This action of oestradiol could be seen also in islets from sham-operated rats, suggesting that oestradiol did not merely reverse an ovariectomy-induced inhibiting effect, better observed in other experimental conditions [5]. The pattern of insulin response to glucose, particularily in the ovariec-
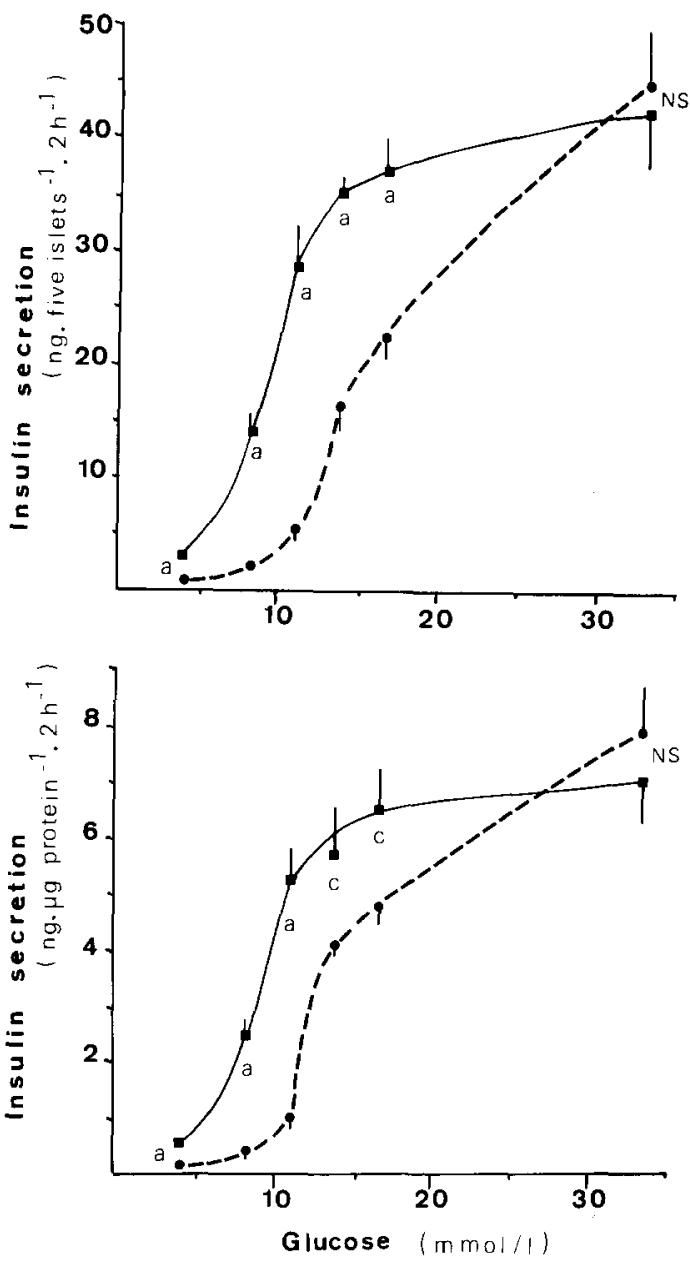

Fig. 2. Insulin secretion from islets of Langerhans isolated from ovariectomized rats treated for 14 days with oestradiol ( $\square-n=6$ ) or with oil vehicle $(--\bullet, n=6)$. Groups of five islets were incubated for $2 \mathrm{~h}$ in the presence of various glucose concentrations. Results are expressed as $\mathrm{ng}$ insulin or $\mathrm{ng} / \mu \mathrm{g}$ islet protein. Values are mean \pm SEM. Statistical analysis is applied for each glucose concentration between control and oestradiol treated groups: ${ }^{\mathrm{a}} p<0.001 ;{ }^{\mathrm{c}} p<0.05$

tomized groups, might be related to an enhanced sensitivity to glucose.

The long-term stimulating effect of oestradiol on insulin secretion in vitro disappeared in adrenalectomized-ovariectomized rats; this agrees with studies in vivo, but in vitro oestradiol did not inhibit insulin secretion as in vivo [11].

Since the presence of adrenal glands was necessary for the stimulating effect of oestradiol on insulin secretion in vitro, a corticosterone supplementation was used to demonstrate the role of glucocorticoids. Corticosterone alone enhanced the magnitude of insulin response and reversed the effect of adrenalectomy + ovariectomy. Oestradiol added to corticosterone again increased the insulin response by enhancing the sensitivity of the $\beta$ cell to glucose, rather than by increasing the magnitude of the insulin response, which was no longer significant for the highest glucose concentration. Thus, the stimulating effect of oestradiol on insulin secretion in 

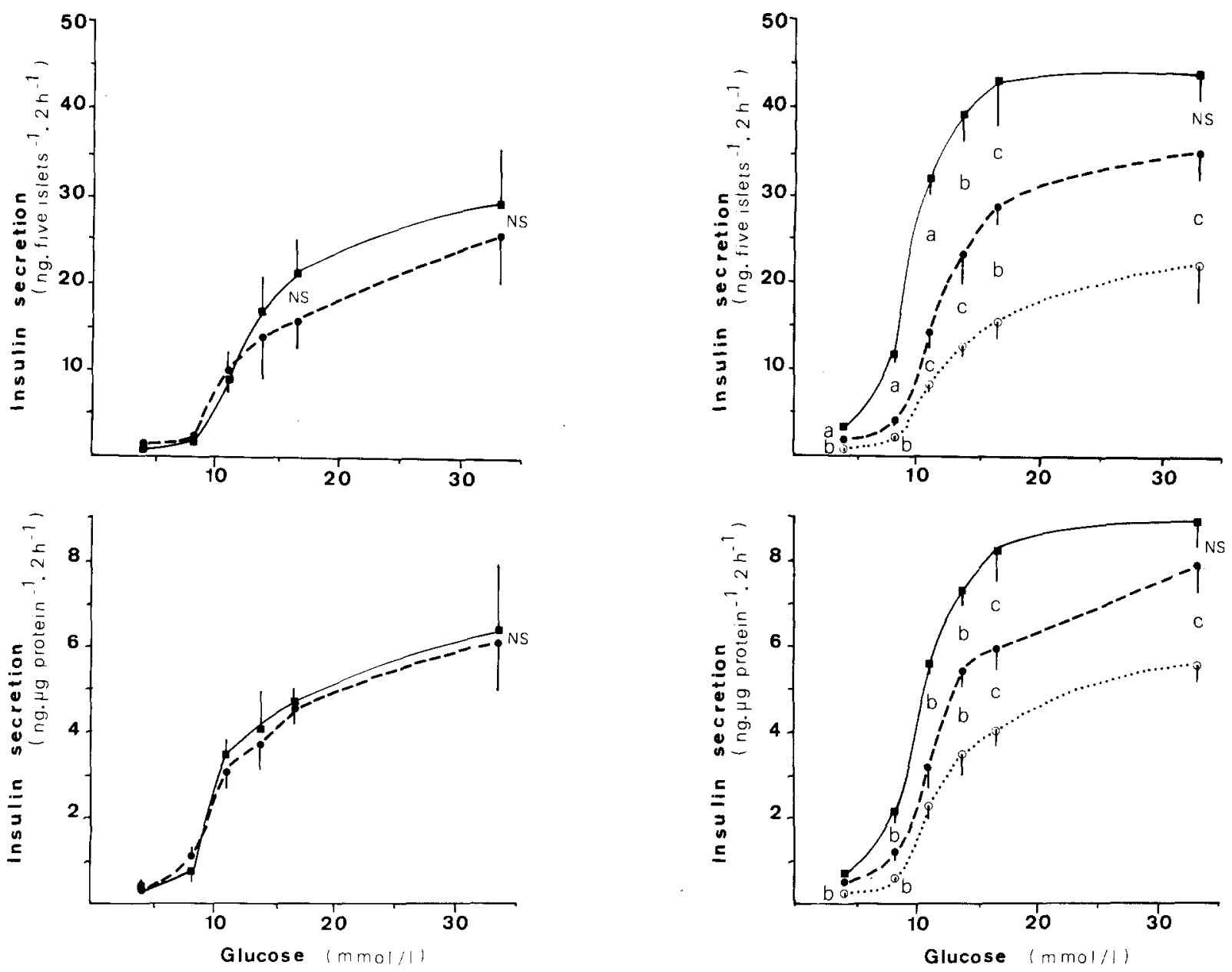

Fig.3. Insulin secretion from islets of Langerhans isolated from adrenalectomized-ovariectomized rats, treated for 14 days with oestradiol ( $\square, n=6$ ) or with oil vehicle $(--\mathbf{\square}, n=11)$. Groups of five islets were incubated for $2 \mathrm{~h}$ in the presence of various glucose concentrations. Results are expressed as ng insulin or $\mathrm{ng} / \mu \mathrm{g}$ islet protein. Values are mean \pm SEM. Statistical analysis is applied for each glucose concentration between control and oestradiol groups: $\mathrm{NS}=$ not significant

vitro was completely restored by corticosterone. This response suggests synergic effects of oestradiol and corticosterone on insulin secretion.

Our data confirm that oestradiol treatment enhances the total protein content of the islets of Langerhans [1] and, moreover, demonstrate that this trophic action does not need the presence of the adrenal gland as does the effect on insulin secretion. The oestradiol induced rise in islet protein content is observed in the absence of adrenal glands or corticosterone, but is not followed by a rise in insulin secretion. This observation does not agree with the hypothesis of Costrini and Kalkhoff [1] which explains an oestrogen-induced insulin hypersecretion in islets from normal rats by a trophic effect of this steroid.

The decrease of islet protein content after adrenalectomy is reversed by corticosterone; this suggests a possible trophic role of corticosterone on islets as al-

Fig. 4. Insulin secretion from islets of Langerhans isolated from ovariectomized-adrenalectomized rats treated for 14 days with corticosterone and oestradiol $(\square, n=5$ ), or with corticosterone alone $(\bullet--\bullet, n=5)$, or with oil vehicle $(\bigcirc \cdots \cdots, n=5)$. Groups of five islets were incubated for $2 \mathrm{~h}$ in the presence of various glucose concentrations. Results are expressed as ng insulin or $n g / \mu \mathrm{g}$ protein. Values are mean \pm SEM. Statistical analysis is applied for each glucose dose ${ }^{\mathrm{a}} p<0.001,{ }^{\mathrm{b}} p<0.01,{ }^{\mathrm{C}} p<0.05$

ready reported after prolonged glucocorticoid treatment [8]. This trophic effect is not oestradiol dependent.

In conclusion, the presence of corticosterone is a prerequisite for the stimulation of insulin secretion by a 14-day oestradiol treatment; in contrast, the oestradiol trophic action on islets of Langerhans is adrenal independent.

Acknowledgements. Novo Laboratories, Paris and Copenhagen, are cordially thanked for the generous gift of rat crystalline insulin. We are grateful to M.T. Roy for technical assistance and to M.H. Davant for typing the manuscript. This work was supported by grants from CNRS AI 30278 and Fondation pour la Recherche Médicale Française.

\section{References}

1. Costrini NV, Kalkhoff RK (1971) Relative effects of pregnancy, estradiol and progesterone on plasma insulin and pancreatic islet insulin secretion. J Clin Invest 50: 992-999 
2. Sutter-Dub M-Th (1976) Preliminary report: effects of female sex hormones on insulin secretion by the perfused rat pancreas. J Physiol [Paris] 72: 795-800

3. Sutter-Dub M-Th (1979) Effects of pregnancy, progesterone and/or oestradiol on the insulin secretion and pancreatic insulin content in the perfused rat pancreas. Diabète Métab 5: 47-56

4. Faure A, Sutter-Dub M-Th (1979) Insulin secretion from isolated pancreatic islets in the female rat. Short and long term oestradiol influence. J Physiol [Paris] 75: 289-295

5. Bailey CJ, Ahmed-Sorour H (1980) Role of ovarian hormones in the long-term control of glucose homeostasis. Effects on insulin secretion. Diabetologia 19:475-481

6. Ingle DJ (1942) The relationship of the diabetogenic effect of diethyl stilbestrol to the adrenal cortex in the rat. Am J Physiol 138: $577-582$

7. Foglia VG, Schuster N, Rodriguez RR (1947) Sex and diabetes. Endocrinology 41: 428-433

8. Haist RE (1965) Effects of steroids on the pancreas. Meth Horm Res 4: 193-233

9. Colby HD, Kitay JI (1974) Interaction of oestradiol and ACTH in the regulation of adrenal corticosterone production in the rat. Steroids 24: $527-536$

10. Mandour T, Kissebah AH, Wynn V (1977) Mechanism of oestrogen and progesterone effects on lipid and carbohydrate metabolism: alteration in the insulin/glucagon molar ratio and hepatic enzyme activity. Eur J Clin Invest 7: 181-187

11. Faure A, Sutter-Dub M-Th, Sutter BChJ, Assan R (1983) Ovarianadrenal interactions in regulation of endocrine pancreatic function in the rat. Diabetologia 24: 122-127

12. Sutter-Dub M-Th, Faure A, Aerts L, Van Assche FA (1978) Effects of progesterone and $17 \beta$-oestradiol treatments on the pancreatic $B$ cell in castrated female rats: biochemical variations. J Physiol [Paris] 74: 725-730
13. Howell SL, Tyhurst M, Green IC (1977) Direct effect of progesterone on rat islets of Langerhans in vivo and in tissue culture. Diabetologia 13: $579-583$

14. Malaisse WJ, Malaisse-Lagae F, McCraw EF, Wright PH (1967) Insulin secretion in vitro by pancreatic tissue from normal, adrenalectomized and cortisol treated rats. Proc Soc Exp Biol Med 124: 924-928

15. Sutter BChJ (1968) Adrenals and plasma insulin in the rat. II. Effect of adrenal cortex. Diabetologia 4: 295-304

16. Lenzen S (1976) The effect of hydrocortisone treatment and adrenalectomy on insulin and glucagon secretion from the perfused rat pancreas. Endokrinologie 68: 189-197

17. Lacy PE, Kostianovsky M (1967) Method for the isolation of intact islets of Langerhans from pancreas. Diabetes 16: 35-39

18. Herbert V, Lau KS, Gottlieb CW, Bleicher SJ (1965) Coated charcoal immunoassay of insulin. J Clin Endocrinol Metab 25: 1375-1384

19. Bradford MM (1976) A rapid and sensitive method for the quantitation of microgram quantities of protein utilizing the principle of protein-dye binding. Anal Biochem 72: 248-254

Received: 25 February 1983

and in revised form: 9 September 1983

Dr. A. Faure

Université de Bordeaux I

UER de Biologie

Laboratoire d'Endocrinologie

Avenue des Facultés

F-33405 Talence Cédex, France 